\title{
Menntun og aðgengi að sjúkratryggðri tannlæknapjónustu í Noregi
}

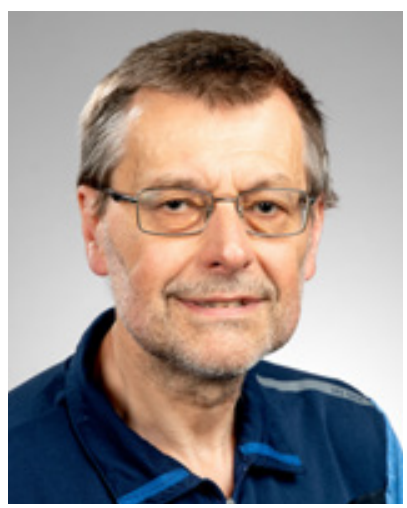

JOSTEIN GRYTTEN, PRÓFESSOR, SVIĐ SAMFÉLAGSTANNLAEKNINGA, TANNLAEKNADEILD, HÁSKÓLINN Í OSLÓ

TENGILIĐUR: JOSTEIN GRYTTEN, SEKSJON FOR SAMFUNNSODONTOLOGY, UNIVERSITETET I OSLO, POSTBOKS 1052, BLINDERN, 0316 OSLO

NETFANG: josteing@odont.uio.no

TANNLAEKNABLAĐIĐ 2020; 38: 81-87

doi: 10.33112/tann.38.1.9

\section{ÁGRIP}

Jafnrétti varðandi aðgengi að heilbrigðispjónustu, p.m.t. tannlækningum, hefur verið veigamikil meginregla við mótun norrænnar velferðarstefnu. Pessi meginregla er mikilvæg forsenda tannverndar fullorðinna sem er fjármögnuð, að hluta eða heild, af sjúkratryggingum. Almennt er talið að með pví að nýta samfélagslega sjóði, sé unnt að draga úr misrétti með aðgengi að slíkri pjónustu. Grein pessi er samantekt á helstu niðurstöðum rannsóknarverkefnis par sem pessi ályktun var sannreynd.

Rannsóknin byggir á gögnum úr opinberum skrám, par sem innleiðing 9 ára grunnskólaskyldu i Noregi var notuð til að skapa breytileika í skólagöngu. Umbæturnar voru kynntar á sveitastjórnarstigi á 13 ára tímabili, frá 1960 til 1972. Fyrir pær var grunnskólaskylda 7 ár. Líta má á breytingarnar sem tilraun par sem einstaklingum er dreift af handahófi í tilraunahóp (9 ára grunnskólanám ) og samanburðarhóp (7 ára grunnskólanám) án pess að stjórnast af viðfangsefni rannsóknar né rannsóknaraðila. Niðurstöður sýna að einstaklingar með lengri skólagöngu hafa betra aðgengi að sjúkratryggðri tannlæknabjónustu og að velferðarkerfi sem byggir á styrkjum nýtist fólki með lengri menntun best.

Lykilorð: Tannvernd, menntun, gjald fyrir pjónustu, endurgreiðsla sjúkratrygginga, orsakasamband

\section{Inngangur}

Jafnrétti varðandi aðgengi að heilbrigðispjónustu, p.m.t. tannlækningum, hefur verið veigamikil meginregla við mótun norrænnar velferðarstefnu (1). Pessi meginregla er grunnforsenda gjaldfrjálsrar tannverndar og tannlæknispjónustu fyrir börn og ungmenni að 18 ára aldri. Talið er óásættanlegt að aðgengi barna og ungmenna að tannlæknispjónustu sé háð fjárhagsstöðu foreldra. Tannlæknispjónusta fjármögnuð með almannafé er opinber sjúkratrygging sem er ætlað að veita öllum börnum og ungmennum, óháð greiðslugetu foreldra og félagslegri stöðu, aðgengi að nauðsynlegri tannlæknispjónustu. Hún er fyrst og fremst veitt af tannlæknum og tannfræðingum sem starfa á opinberum heilsugæslustöðvum á föstum launum.

Að öllu jöfnu er tannlæknispjónusta fullorðinna, á flestum Norðurlandanna, fjármögnuð með öðrum hætti en pjónusta fyrir börn og ungmenni (2). Fullorðnir sækja stærstan hluta pjónustunnar til sjálfstætt starfandi tannlækna sem vinna samkvæmt einingaverði á samkeppnismarkaði. Yfirvöld telja mikilvægt, í mismiklum mæli pó, að efnahagur fullorðinna 
og félagsleg staða hafi ekki afgerandi áhrif á aðgengi peirra að pjónustunni. Til að forðast félagslega mismunun i aðgengi fullorðinna að tannlækningum hefur verið nokkuð um að sjúkratryggingar endurgreiði tannlæknispjónustu á grundvelli einingaverðs (3). Miðað við tiltekin parfaviðmið endurgreiðir ríkið kostnað við tannlækningar að hluta eða í heild.

Helsti ókostur við fjármögnun sjúkratrygginga á grundvelli endurgreiðslu á einingaverði er takmörkuð geta sjúkratrygginga til að stjórna kostnaði $(4,5)$. Annar alvarlegur ókostur, sem sjaldan er rætt um, er að pjónustan nái hugsanlega ekki til nægilega margra. Pað er ekki sjálfgefið að fjármögnun sjúkratrygginga sem byggist eingöngu á endurgreiðslum samkvæmt einingaverði nýtist nógu vel peim sem mest purfa á pví að halda. Forsenda pess að geta nýtt sjúkratryggingar er að sjúklingurinn leiti til tannlæknis og að tannlæknirinn bjóði viðeigandi meðferð. Hins vegar er ekki tryggt að allir sjúklingar með mikla læknispörf leiti til tannlæknis, jafnvel pótt fjárhagslegar hindranir verði minnkaðar eða peim rutt úr vegi (sjá yfirlit yfir nýlegar heimildir nr. 6-8). I pessari grein er varpað ljósi á mikilvægi félagslegrar stöðu, mældri eftir lengd skólagöngu. Rannsóknarspurningin varðar pað hvort aðgengi fullorðinna Norðmanna að sjúkratryggðri tannlæknispjónustu sé háð menntunarstigi peirra.

Markmiðið með greininni er að taka saman helstu niðurstöður rannsókna par sem varpað er ljósi á kosti sjúkratryggðrar tannlæknapjónustu á grundvelli einingaverðs (9-11). Yfirskrift verkefnisins er: Hver fær og hver fær ekki? Gagnsemi aukinnar sjúkratryggðrar tannlæknispjónustu. Rannsóknirnar byggja á innlendum úrtaksgögnum. Kostur við slík gögn er að hægt er að greina orsakasamhengi milli menntunar og aðgangs að tannlæknispjónustu. Greiningaraðferðin hefur reynst vel undanfarinn áratug við rannsóknir á orsakasamhengi með hvaða hætti menntun hefur áhrif á heilsufar og aðgengi að heilbrigðispjónustu (12-15). Sambærilegar norrænar rannsóknir eru: Meghir et al. (2018), Fisher et al. (2015), Grytten et al. (2014), Grytten et al. (2020) (16-19). Hér á eftir verður fjallað um mikilvægustu pættina i aðferðafræði, niðurstöður og pólitískar afleiðingar.

\section{Efni og aðferð}

\section{Aðhvarf - algengasta greiningaraðferðin}

Skilningur á empírískri aðferðafræði er forsenda pess að hægt sé að varpa ljósi á vandamálið. Venjuleg aðhvarfsgreining (OLS eða Ordinary Least Squares) getur hæglega gefið villandi niðurstöður (14, 20, 21). pað stafar að hluta til af pví að erfitt er að stjórna öllum hugsanlegum aukabreytum, pá einkum breytum sem ekki eru auðmælanlegar (t.d. færni).
Einnig getur reynst erfitt að ákvarða hvaða stýri- eða leiðréttingabreytur ætti að taka með í greiningunni (22). Ef ekki eru notaðar réttar stýribreytur getur í versta falli gerst að orsakapáttur sem æskilegt væri að taka með félli út. Að auki er vandasamt að taka tillit til öfugs orsakasamhengis; p.e. að heilsufar einstaklingsins hefur einnig áhrif á menntunarstigið.

Ein algengasta orsök skekkja í niðurstöðum er að ekki er tekið mið af áhrifum aukabreytna sem tengjast bæði lengd skólagöngu og líkum á pví að geta nýtt sér sjúkratryggðar tannlækningar. Vel pekkt dæmi um slíkt eru færni (e. abilities), búseta, tímatengdar aðstæður og tannsjúkdómar (20,23, 24). Til dæmis er líklegra að greindari einstaklingar sæki sér æðri menntun og leiti samhliða pví til tannlæknis pegar pess er pörf, borið saman við minna greinda einstaklinga. Einstaklingar með lengri menntun eru einnig líklegri til að setjast að í félagslega betur settum hverfum/svæðum landsins, en minna menntaðir einstaklingar. Á efnameiri svæðum er framboð vandaðra skóla og góðrar tannlæknapjónustu jafnan best. Of lítil stjórn á tímatengdum breytum getur einnig valdið skekkjum. Einstaklingar sem hugsa til lengri tíma eru líklegri til að fjárfesta í menntun og í nauðsynlegri tannlæknispjónustu, en einstaklingar sem lifa meira í núinu (25). Par sem hæfileikar, búseta og tímatengdar aðstæður eru jákvætt tengdar bæði menntun og líkum á að fá meðferð, verður vægi menntunar of mikið (bjögun upp á við) ef pessar breytur eru ekki teknar með í aðhvarfsgreiningunni. Tannsjúkdómar eru jákvætt tengdir meðferð en neikvætt menntun. Par af leiðandi verður vægi menntunar of lítið (bjögun niður á við) ef ekki er tekið mið af tannsjúkdómum í aðhvarfsgreiningunni.

\section{Slembival - næstum ómögulegt pegar menntun er notuð sem skýringabreyta (eksponeringsvariabel)}

Dæmi um gott rannsóknarsnið væri að slembiraða pýðinu í hópa með innbyrðis mun á lengd skólagöngu (26). Röksemdafærslan er sú að hending ræður hvaða einstaklingar lenda í mismunandi hópum (slembival). Með pví móti verða hóparnir ápekkir hvað varðar alla eiginleika aðra en lengd skólagöngu, sem fær pá mikið vægi í niðurstöðum. Ef við skoðum mun á svörum milli hópanna getum við dregið pá ályktun að petta sé vegna misjafnrar lengdar menntunar og einskis annars. Af nokkrum ástæðum, par á meðal siðferðilegum, kostnaðarlegum og hagnýtum ástæðum, er slík tilraun ekki raunhæf.

\section{Náttúrulegar tilraunir og umbætur í skólum}

Síðustu tvo áratugi hafa faraldsfræðilegar og efnahagslegar faggreinar notað náttúrlegar tilraunir til að ná fram slembi- 
vali. Pá er einstaklingum slembiraðað í tilrauna- og samanburðarhóp á grundvelli náttúrulegra aðstæðna sem hvorki rannsóknarpýðið né rannsóknaraðilar geta haft stjórn á $(27,28)$. Náttúrulegar tilraunir orsakast oft af pólitískum umbótum, svo sem innleiðingu 9 ára skólagöngu. Slíkar umbætur í skólum voru kynntar í flestum löndum VesturEvrópu, Bandaríkjum og Kanada á mismunandi tímabilum síðustu aldar. Pær hafa gjarnan falist i fjölgun skólaskylduára úr sjö i níu. Umbæturnar voru innleiddar á landsvísu og náđu til allra barna á grunnskólaaldri. Tímasetning innleiðingar voru tilviljanakenndar og tengdust ekki pekktum eða ópekktum eiginleikum barna. Pannig urðu til tveir hópar: Hópur barna og ungmenna með 7 ára skólagöngu (samanburðarhópur) og hópur með 9 ára skólagöngu (tilraunahópur). Fæðingarár barna og innleiðingartími endurbótanna réði pví í hvorn hópinn börnin voru sett. Margir vísindamenn hafa notað pessar umbætur í skóla til að meta orsakasamband menntunar við ýmis heilsufarsgögn (dánartíðni og sjúkdóma) og á lýðheilsu. Nokkrar veigamiklar greinar par sem aðferðin og mikilvægustu niðurstöður eru teknar saman eru: Galama et al. (2018), Grossman (2015), Eide og Showalter (2011), Gathman et al. (2015) og Glymour og Manly (2018) (12-15, 29).

Umbætur í skólastarfi eru sérstaklega hentugar við greiningu á ómælanlegum og ósýnilegum eiginleikum einstaklinga. pað pýðir að við getum áætlað áhrif lengdar skólagöngu, jafnvel pótt við höfum ekki gögn um einstaklingsbundna eiginleika, svo sem færni, búsetu, tímatengdar aðstæður og tannsjúkdóma (30-32). Við greiningu er stuðst við opinberar skrár. pessi gögn varða alla íbúa landsins og innihalda viðeigandi upplýsingar til langs tíma. Greiningartæknin krefst viðamikillar tölvuvinnslu. Hins vegar hefur upplýsingatæknibyltingin undanfarna áratugi auðveldað greiningar á gagnamagni sem er orðið aðgengilegt í gegnum stór gagnasöfn.

\section{Innleiðing 9 ára skólaskyldu í Noregi}

í Noregi var 9 ára grunnskólaskylda innleidd á 13 ára tímabili, frá 1960-1972 $(33,34)$. Fyrir breytingar hófu börn skólagöngu 7 ára og luku skyldunámi 14 ára. Eftir breytingar hófst skólagangan einnig við 7 ára aldur, en lauk við 16 ára aldur. Á tímabilinu 1960 til 1972 var sveitarfélögum frjálst að ákveða hvenær breytingarnar skyldu innleiddar. Pess vegna var í raun tvöfalt skólaskyldukerfi við lýði í Noregi á pessu tímabili. Sum sveitarfélög innleiddu breytingarnar snemma, önnur seint (Mynd 1). Par af leiddi að skólaganga einstaklinga í sama sveitarfélagi gat verið mislöng. Pess vegna er hægt að bera saman líkur á að njóta sjúkratryggðrar tannlæknapjónustu fyrir annars vegar einstaklinga með 9 ára grunnskólagöngu og hins vegar einstaklinga með skemmri skólagöngu (9-11).

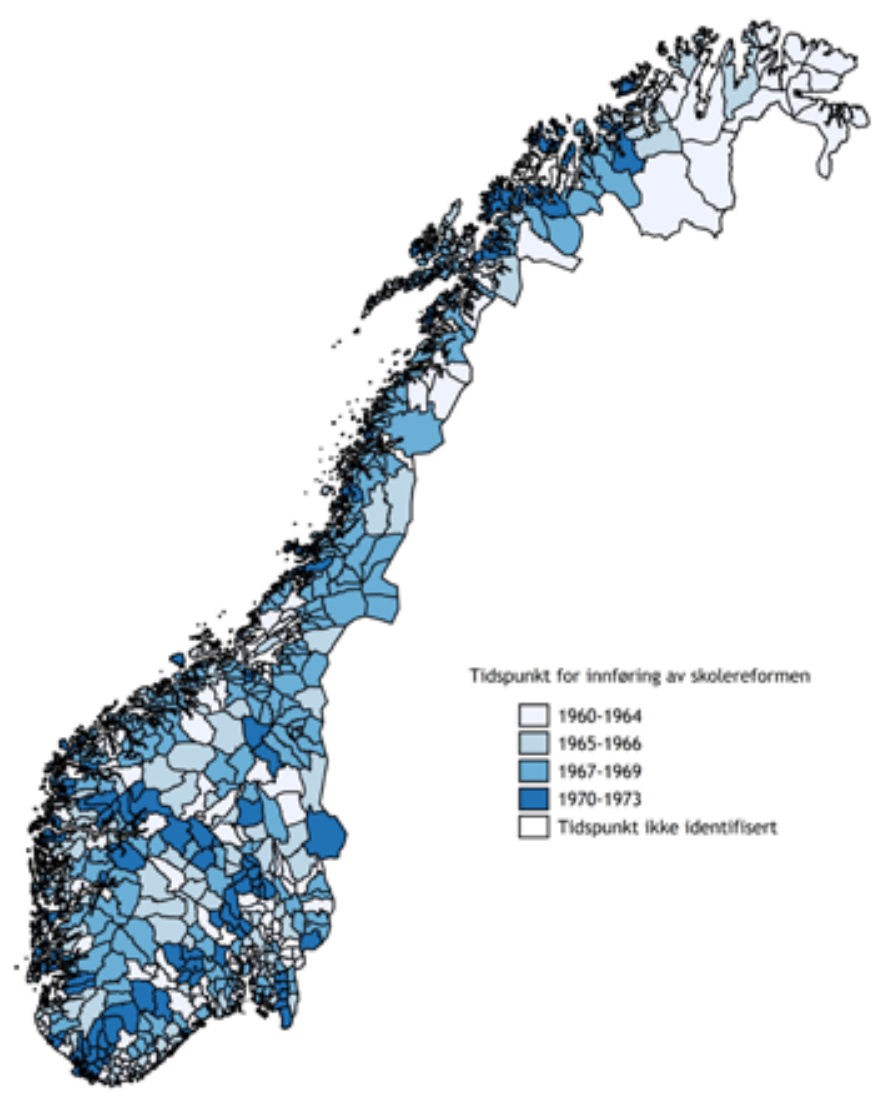

Mynd 1. Tími innleiðingar á skólaumbótum

\section{Mat með hjálparbreytum}

Stöðluð aðferð við að meta áhrifapætti î náttúrulegum tilraunum, svo sem innleiðingu 9 ára skólaskyldu, er að nota hjálparbreytur. Pessari tækni er vel lýst í kennslubókum og fræðigreinum og pví ekki farið nánar út í hana hér (30-32, 35). Við látum okkur nægja að gefa stutta kynningu á hugmyndinni að baki aðferðinni sem byggist á mynd 2 . Aðferðin felur í sér tveggja prepa aðhvarfslíkan.

I fyrra prepi er lengd menntunar háð breytu sem skýrist af tilkomu skólaumbóta. Pessi breyta felur í sér mismun á lengd menntunar sem ræðst eingöngu af pví hvort einstaklingurinn var með 9 ára skólaskyldu eða ekki.

Á seinna prepi eru spágildi úr fyrra prepi notuð til að meta líkurnar á bví að einstaklingar njóti sjúkratryggðrar tannlæknapjónustu. Forsendan er sú að hvort sem 


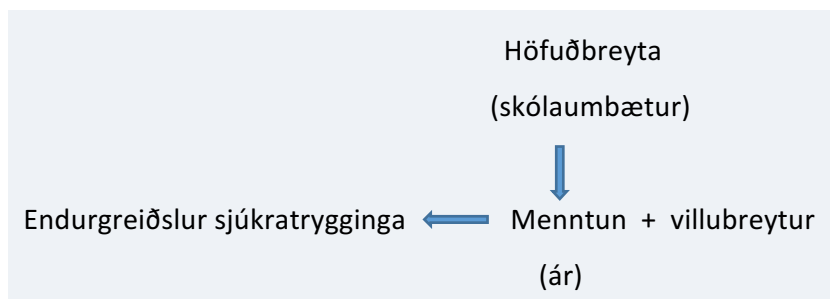

Mynd 2. Mat á orsakartengdum áhrifum hjálparbreyta

einstaklingur hefur farið í gegnum úrbætur í skólamálum eða ekki, hefur pað aðeins áhrif á peim tíma sem ætlað er að skólaskyldan standi. Petta er trúverðug forsenda, par sem hvorki rannsóknaraðilar né rannsóknarpýđi réð pví hvenær úrbætur voru innleiddar í einstökum sveitarfélögum.

\section{Gögn, útkomumarkmið og aðhvarfslíkan}

Í greiningunum eru gögn um innleiðingartíma skólaumbótanna tengd við gögn sem sýna hvort einstaklingur hefur nýtt sér sjúkratryggðrar tannlæknapjónustu. Síðarnefndu gögnin eru sótt í rafrænan gagnagrunn fyrir eftirlit með og greiðslur úr sjúkratryggingasjóði (KUHR) í umsýslu norska landlæknisembættisins (https://www. helsedirektoratet. no/tema/statistikk-registre-og-rapporter/helsedata-oghelseregistre/kuhr). Hagstofa Noregs hefur upplýsingar um fæðingardag og búsetu einstaklinga allt aftur til ársins 1960. Pannig getum við tengt aðgengi að sjúkratryggðri tannlæknapjónustu á endurgreiðslum almannatrygginga beint við pað hvort viðkomandi var með 9 ára skólaskyldu eða ekki á tímabilinu 1960-1972 (https://www.ssb.no/ utdanning/norsk-standard-for-utdanningsgruppering).

Rannsóknarverkefnið tengdi saman mismunandi gerðir gagna og krafðist pví sampykkis svæðissiðanefndar læknisfræði og heilbrigðisrannsókna (verkefnanúmer 2013/1844). Yfirlitsgreinin krafðist ekki sérstaks sampykkis.

Niðurstöðurnar úr öðru prepi aðhvarfsrannsóknarinnar eru kynntar með hliðsjón af premur útkomumarkmiðum:

- líkum á að njóta sjúkratryggðrar tannlæknispjónustu vegna allra tegunda meðferða

- líkum á að njóta sjúkratryggðrar tannlæknispjónustu vegna tannholdsmeðferðar

- líkum á að njóta sjúkratryggðrar tannlæknispjónustu vegna tanngerva, par með taldir tannplantar

Í Noregi parf sjúklingurinn að greiða tiltekinn hluta kostnaðarins, par með talið fyrir skoðanir, jafnvel pótt viðkomandi meðferð falli undir sjúkratryggingar. Hlutur sjúklingsins er breytilegur eftir gerð og umfangi meðferð- arinnar. Upphæðin er hærri fyrir tanngervi en fyrir tannholdsmeðferðir. Pað er pví hugsanlegt að munurinn á menntunarstiginu sé mestur par sem hlutur sjúklingsins er hæstur.

Notað er línulegt aðhvarfslíkan við allar greiningar (36). Aðhvarfsstuðulinn má svo túlka sem breytingar á líkum á pví að njóta sjúkratryggðrar tannlæknapjónustu, sýnt í prósentum, ef skólaskyldan lengist um eitt ár. Petta er mælikvarði á algilda breytingu. Við setjum einnig fram hlutfallslega breytingu sýnda í prósentum.

\section{Niðurstöður}

Er aðgengi að sjúkratryggðri tannlæknispjónustu háð menntun?

I öllum greiningum okkar virðist ljóst að líkurnar á að njóta sjúkratryggðar tannlæknapjónustu aukast samhliða lengri skólaskyldu; p.e. einstaklingar með lengri menntun eru líklegri til að nýta sér pjónustuna (tafla 1). Pegar allar tegundir meðferða eru teknar sem heild, eru áhrifin 2 prósentustig eða $15 \%$ pegar pau eru gefin upp hlutfallslega.

Eins og vænta má eru áhrifin mest hvað varðar tanngervi, par með talin smíði á tannplanta. Hjá karlmönnum aukast líkurnar á tanngervum um 30\% við lengingu skólagöngu sem nemur einu ári. Hjá konum eru engin merkjanleg áhrif. Fyrir hin tvö útkomumarkmiðin eru áhrifin eins hjá körlum og konum.

\section{Áhrif menntunar eru vanmetin í venjulegri aðhvarfsgreiningu}

Í töflu 1 eru einnig kynntar niðurstöður úr staðlaðri aðhvarfsgreiningu (OLS). Fyrir öll útkomumarkmiðin er annars stigs matið um pað bil tvöfalt hærra en mat úr venjulegri aðhvarfsgreiningu benti til. petta bendir til pess að tannsjúkdómar séu veigamikil undirliggjandi breyta sem hefur ekki verið tekin til greina i mati i venjulegri aðhvarfsgreiningu. Færni, búseta og tímatengdar aðstæður eru ólíklegri til að vera veigamiklar undirliggjandi breytur. Pað stafar af pví að mat úr venjulegri aðhvarfsgreiningu er skekkt í átt að 0 („hlutdrægni niður á við“).

Munurinn á mati úr venjulegri aðhvarfsgreiningu og annars stigs mati undirstrikar mikilvægi pess að nota uppsetningu og greiningaraðferð par sem bæði sýnilegar og ósýnilegar breytur eru skoðaðar.

\section{Umræður - staðreyndir og möguleikar}

Aðeins eru til fáar rannsóknir sem hafa varpað ljósi á dreifingu áhrifa af sjúkratryggðri tannlæknapjónustu. Pó er til lýsandi rannsókn par sem niðurstöður eru í samræmi við niðurstöður okkar. Í evrópskri rannsókn (könnun) sem tók til 11 


\section{Tafla 1. Áhrif menntunar á likur á bví að einstaklingur nýti sér sjúkratryggða tannlæknispjónustu}

\begin{tabular}{|c|c|c|c|}
\hline & $\begin{array}{c}\text { Líkur á að fá } \\
\text { endurgreiðslu } \\
\text { sjúkratrygginga, allar } \\
\text { meðferðir }^{1}\end{array}$ & $\begin{array}{c}\text { Líkur á að fá } \\
\text { endurgreiðslu } \\
\text { sjúkratrygginga vegna } \\
\text { tannholdsmeðferða² }\end{array}$ & $\begin{array}{c}\text { Líkur á að fá endurgreiðslu } \\
\text { sjúkratrygginga vegna } \\
\text { tanngerva, tannplantar } \\
\text { medtaldir }{ }^{3}\end{array}$ \\
\hline Breytur & Bæði kyn & Bæði kyn & Karlar \\
\hline Tveggja prepa aðhvarfsgreining & 0,020 & 0,017 & 0,0067 \\
\hline Hlutfall sem fengu endurgreiðslu sjúkratrygginga & 0,13 & 0,10 & 0,022 \\
\hline $\begin{array}{l}\text { Aukning i \% sem fengu endurgreiðslu sjúkratrygginga } \\
\text { pegar skólaganga jókst um eitt ár }\end{array}$ & $15 \%$ & $17 \%$ & $30 \%$ \\
\hline Venjuleg Least Squares aðhvarfsgreining & 0,010 & 0,006 & 0,0039 \\
\hline Fjöldi einstaklinga & 84599 & 90528 & 53544 \\
\hline
\end{tabular}

1 Grytten J, Skau I. Do patients with more education receive more subsidized dental care? Evidence from a natural experiment using the introduction of a school reform in Norway as an instrumental variable. Med Care 2018;56:877-82.

2 Grytten J, Skau I. The impact of education on the probability of receiving periodontal treatment. Causal effects measured by using the introduction of a school reform in Norway. Soc Sci Med 2017;188:128-36.

3 Grytten J, Skau I. Inequalities according to level of education in access to fixed prosthodontic treatment in Norway. Causal effects using the introduction of a school reform as an instrumental variable. Manuscript 2020.

landa kom í ljós að jafnvel í löndum með sjúkratryggða tannlæknapjónustu var aðgengi að pjónustunni betra fyrir fólk með meiri menntun en fyrir minna menntaða einstaklinga (37). Á öllum Norðurlöndunum er stærstur hluti tannlæknispjónustu sem stendur fullorðnum til boða veittur af sjálfstætt starfandi tannlæknum (3). Umfang sjúkratryggðrar tannlæknapjónustu er mismunandi eftir löndum. En í öllum pessum löndum er meginreglan sú að opinber tryggingakerfi fyrir tannlækningar byggja á endurgreiðslu samkvæmt einingaverði (3). Við förum auðvitað varlega í að heimfæra okkar niðurstöður yfir á öll hin Norðurlöndin. Á grundvelli pess hve margt er líkt í skipulagi og fjármögnun tannlæknispjónustu er engu að síður ástæða til að ætla að niðurstöður frá Noregi geti einnig átt við um hin löndin.

Ekki blasir við með hvaða hætti er hægt að draga úr eða mögulega eyða peim mismun sem er á milli pess hversu gott aðgengi fólk með mislanga skólagöngu hefur að sjúkratryggðri tannlæknapjónustu. Einn valkostur er að grípa til ráostafana sem hvetja fólk til að nýta pjónustuna, til dæmis með pví að bjóđa upp á upplýsingar um almannatryggingakerfin sem auðvelt er að skilja, jafnvel fólki með skamma skólagöngu. Hins vegar er ekki hægt að útiloka að einhver munur verði áfram til staðar, prátt fyrir upplýsingaherferðir.

Grundvallarspurningin er hins vegar sú hvort núverandi fjármögnun almannatrygginga sem byggist á endurgreiðslu samkvæmt einingaverði sé nægilega skilvirk til að jafna upp mismuninn vegna lengdar skólagöngu. Augljós veikleiki núverandi kerfis er að aðeins peir sem leita tannlækninga njóta góđs af pví. Reynslan sýnir að pessir sjúklingar eru einnig með minnstu pörfina og hæstu tekjurnar (38). Með öðrum orðum, peir einstaklingar sem hafa minnstu pörfina fá mest. petta kallar á úrbætur á sviði skipulags og/eða fjármögnunar, sem myndu miða að pví að ná betur til einstaklinga sem núverandi kerfi grípur ekki sem stendur.

Hér eru valkostirnir fleiri. Hvað varðar skipulag mætti hugsa sér að bjóða upp á forvirka pjónustu með lágu kostnaðarpaki. Pessu mætti beina sérstaklega að einstaklingum með skamma skólagöngu sem sjaldan eða aldrei leita til tannlæknis. Hvað varðar fjármögnun er einn möguleiki að fela tannlæknum skilgreint ábyrgðarhlutverk gagnvart almenningi $(39,40)$. Petta má gera með pví að innleiða heimilistannlæknakerfi par sem endurgreiðsla miðast að hluta við hvern íbúa, eins og gert hefur verið fyrir hluta af fullorðnum íbúum Svíbjóðar (3). Pannig er hægt að styrkja tengslin milli tannlæknis og sjúklings - sjúklingar vita hvaða tannlæknis peir eiga rétt á að leita til og tannlæknarnir vita hvaða sjúklingum peir eru ábyrgir fyrir. petta getur stuðlað að auknu öryggi í sambandi tannlæknis og sjúklings, meðal annars með tryggu aðgengi. Tannlæknirinn ber pá ábyrgð á pví að bjóða upp á viððtækt úrval meðferðar fyrir alla sína sjúklinga, óháð lengd skólagöngu, par með talið fyrir pá sem hafa ríka pörf fyrir meðferð.

Í rannsókninni nýttum við okkur náttúrulega tilraun par sem hægt var að gefa sér að einstaklingar skiptust handahófskennt i tvo hópa: hóp barna og ungmenna með 7 ára skólagöngu (samanburðarhóp) og hóp með 9 ára skólagöngu (tilraunahóp). Hugsunin að baki peirri nálgun er sú að skoða mögulegar priðju breytur sem geta tengst 
bæði lengd menntunar og líkum á að einstaklingur nýti sér sjúkratryggða tannlæknapjónustu. Helsti kosturinn við rannsóknaraðferðina er sá að hægt er að staðfesta hvort tekist hefur að útiloka mögulegar priðju breytur. petta er hægt að gera á að minnsta kosti tvo vegu (9-11).

Í fyrsta lagi er hægt að gera lyfleysupróf. petta er eins og tilraun par sem við ímyndum okkur að skólaumbætur hafi hafist fyrr en pær hófust í raun. Í slíkri tilraun ættu umbæturnar ekki að hafa nein áhrif á útkomubreyturnar. Ef áhrif koma fram verður að tengja hjálparbreytuna (= skólaumbæturnar) við eina eða fleiri priðju breytur. Í reynd pýðir petta að aðgengi að sjúkratryggðri tannlæknapjónustu ræðst af öðrum aðstæðum en lengd menntunar. Við framkvæmdum lyfleysupróf í öllum rannsóknum okkar (9-11). Í pessum prófum fundum við engin áhrif af lengd skólagöngu á líkurnar á pví að einstaklingur nýti sér sjúkratryggða tannlæknapjónustu. Рað bendir til pess að niðurstöður okkar, sem greint er frá í töflu 1, sé hægt að skýra með lengd menntunar en ekki með einni eða fleiri priðju breytum.

Í öðru lagi getum við lengt raunverulega greiningu á hjálparbreytum með pví að taka með sjáanlegar leiðréttingarbreytur. Við skoðum síðan hvort mat úr aðhvarfsgreiningu reynist frábrugðið með og án leiðréttingarbreytna. Reynist svo vera bendir pað til pess að innleiðingartími skólaumbótanna sé ekki handahófsbreyta heldur tengist beint öðrum veigamiklum leiðréttingarbreytum. Forsenda um slembival er pá ekki til staðar. Við gerðum viðbótargreiningar með nokkrum gerðum leiðréttingarbreytna á einstaklingsgrundvelli: kyni, hjúskaparstöðu, atvinnuástandi, tekjum heimilis fyrir og eftir skatta og örorkulífeyri (9-11). Mat úr aðhvarfsgreiningu, sem greint var frá í töflu 1, breyttist ekki pegar pessar breytur voru teknar með í greiningarnar.

Fyrirliggjandi rannsóknir og gögn sem stuðst er við í rannsókn okkar, sem nýtir skólaumbætur til að leggja mat á orsakaáhrif menntunar á mun á aðgengi að heilbrigðispjónustu (yfirlit yfir heimildir frá ýmsum löndum er að finna í heimildum nr. 12-15), eru með peim takmörkunum að gæði peirrar menntunar sem er boðið upp á eru ekki mæld sérstaklega. Gert er ráð fyrir að tengsl séu milli lengdar og gæða menntunar, mæld sem námsárangur. Til lengri tíma litið er líklegt að sú ályktun sé rétt. Engu að síður er pað takmörkun í fyrirliggjandi gögnum og heimildum á pessu sviði, en verður vonandi kannað betur með rannsóknum á komandi árum.

\section{Niðurstaða}

Fjármögnun almannatrygginga sem byggist á endurgreiðslum á einingaverði er ríkjandi fyrirmynd sem stjórnvöld nota í dag til að dreifa fé til tannlæknismeðferðar til fullorðinna. Niðurstöður okkar benda til pess að með hliðsjón af dreifingu sé ekki einsýnt að í framtíðinni ætti petta að vera eina aðferðin við úthlutun úr slíkum almannatryggingasjóðum. Fjármögnunarlíkanið tryggir ekki sjálfkrafa jafnræði í framboði á heilbrigðispjónustu sem er fjármögnuð af almannatryggingum miðað við menntunarstig íbúanna. Pvert á móti sýna niðurstöðurnar mun á pví hver fær og hver fær ekki endurgreiðslur frá almannatryggingum. Rannsóknirnar eru gerðar með hliðsjón af innleiðingu skólaumbóta í Noregi og greiningaraðferð sem byggir á orsakasamhengi.

\section{Heimildir}

1. Holst D. Varieties of oral health care systems. Public dental services: organisation and financing of oral health care services in the Nordic countries. İ: Pine CM, Harris E, ritstj. Community Oral Health. 2. útg. New Malden, Surrey: Quintessence Publishing, 2007:283-91.

2. Widström E, Ekman A, Aandahl LS et al. Developments in oral health policy in the Nordic countries since 1990. Oral Health Prev Dent 2005;3:225-35.

3. Bilde L, Bækø C, Kiil A. Hvad ved vi om brugerbetaling og efterspørgsel efter voksentandpleje? - Del II: International sammenligning af erfaringer med brugerbetaling i voksentandplejen. VIVE 2018

4. Grytten J. Models for financing dental services. A review. Community Dent Health 2005;22:75-85.

5. Evans RG, Williamson MF. Extending Canadian health insurance: options for pharmacare and denticare. 1. útg. Toronto: University of Toronto Press, 1978.

6. Grytten J. The Norwegian dental care market. Empirical studies on accessibility and supplier inducement in the adult population [doktorsritgerð]. Oslo: Universitetet i Oslo, 1992.

7. Somkotra $T$, Detsomboonrat $P$. Is there equity in oral healthcare utilization: experience after achieving Universal Coverage. Community Dent Oral Epidemiol 2009;37:85-96.

8. Maserejian NN, Trachtenberg F, Link C et al. Underutilization of dental care when it is freely available: a prospective study of the New England Children's Amalgam Trial. J Public Health Dent 2008;68:139-48.

9. Grytten J, Skau I. Do patients with more education receive more subsidized dental care? Evidence from a natural experiment using the introduction of a school reform in Norway as an instrumental variable. Med Care 2018;56:877-82.

10. Grytten J, Skau I. The impact of education on the probability of receiving periodontal treatment. Causal effects measured by using the introduction of a school reform in Norway. Soc Sci Med 2017;188:128-36.

11. Grytten J, Skau I. Inequalities according to level of education in access to fixed prosthodontic treatment in Norway. Causal effects using the introduction of a school reform as an instrumental variable. Manuskript 2020.

12. Galama T, Lleras-Muney A, van Kippersluis $H$. The effect of education on health and mortality: a review of experimental and quasi-experimental evidence. Oxford Research Encyclopedia of Economics and Finance 2018.

13. Grossman M. The relationship between health and schooling? What's new? Nordic J Health Econ 2015;3:7-17.

14. Eide ER, Showalter MH. Estimating the relation between health and education: what do we know and what do we need to know? Econ Edu Rev 2011;30:778-91.

15. Gathmann $C$, Jürges $H$, Reinhold $S$. Compulsory schooling reforms, education and mortality in twentieth century Europe. Soc Sci Med 2015;127:74-82.

16. Meghir C, Palme M, Simeonova E. Education and mortality: evidence from a social experiment. Am Econ J Appl Econ 2018;10:234-56.

17. Fischer M, Karlsson M, Nilsson T. Effects of compulsory schooling on mortality: evidence from Sweden. Int J Environ Res Public Health 2013;10:3596-618. 
18. Grytten J, Skau I, Sørensen RJ. Educated mothers, healthy infants. The impact of a school reform on the birth weight of Norwegian infants 1964-2005. Soc Sci Med 2014; 105:84-92.

19. Grytten J, Skau I, Sørensen R. Who dies early? Education, mortality and causes of death in Norway. Soc Sci Med 2020;245:112601.

20. Grossman M. Education and nonmarket outcomes. I: Hanushek EA, Welch F, ritstj. Handbook of the Economics of Education. 2. útg. Amsterdam: Elsevier, 2006.

21. Listl S, Jürges H, Watt RG. Causal inference from observational data. Community Dent Oral Epidemiol 2016;44:409-15.

22. Grytten J. The impact of education on dental health - ways to measure causal effects. Community Dent Oral Epidemiol 2017;45:485-95.

23. Oreopoulos P, Salvanes KG. Priceless: the nonpecuniary benefits of schooling. J Econ Perspect 2011:25:159-84.

24. Grossman N, Kaestnar R. Effects of education on health. Í: Behrman JR, Stacey N, ritstj. The Social benefits of education. 1. útg. Ann Arbor: The University of Michigan Press, 1997

25. Fuchs VR. Time preference and health: an exploratory study. Í: Fuchs VR, ritstj. Economic aspects of health. 1. útg. Chicago: University of Chicago Press for the National Bureau of Economic Research, 1982:93-120.

26. Deaton $\mathrm{A}$, Cartwright $\mathrm{N}$. Understanding and misunderstanding randomized controlled trials. Soc Sci Med 2018;210:2-21.

27. Rassen JA, Brookhart MA, Glynn RJ et al. Instrumental variables I: instrumental variables exploit natural variation in nonexperimental data to estimate causal relationships. J Clin Epidemiol 2009;62:1226-32.

28. Deaton A. Instruments, randomization, and learning about development. J Econ Lit 2010;48:424-55.
29. Glymour MM, Manly JJ. Compulsory schooling laws as quasi-experiments for the health effects of education: reconsidering mechanisms to understand inconsistent results. Soc Sci Med2018;214:67-9.

30. Angrist JD, Pische JS. Mostly harmless econometrics. An empiricists's companion. 1. útg. Princeton: Princeton University Press, 2009:113-218.

31. Stock JH. Instrumental variables in statistics and econometrics. İ: Smelser NJ, Baltes P, ritstj. International encyclopedia of the social behavioral sciences. Amsterdam: Elsevier, 2001:7577-82.

32. Wooldridge JM. Introductory econometrics. A modern approach. International edition. 5. útg. South-Western: Cengage Learning, 2013:64-108, 490-557.

33. Lie SS. Regulated social change: a diffusion study of the Norwegian comprehensive school reform. Acta Sociol 1973;16:332-52.

34. Telhaug AO. Den 9-årige skolen og differensieringsproblemet. En oversikt over den historiske utvikling og den aktuelle debatt. Oslo: Lærerstudentenes Forlag, 1969.

35. Martens EP, Pestman WR, de Boer A et al. Instrumental variables. Application and limitations. Epidemiology 2006;17:260-7.

36. Angrist JD. Estimation of limited dependent variables models with dummy endogenous regressors. J Bus Econ Stat 2001;19:2-28.

37. Palència L, Espelt A, Cornejo-Ovalle M et al. Socioeconomic inequalities in the use of dental care services in Europe: what is the role of public coverage? Community Dent Oral Epidemiol 2014;42:97-105.

38. Grytten J, Holst D, Skau I. Demand for and utilization of dental services according to household income in the adult population in Norway. Community Dent Oral Epidemiol 2012:40:297-305

39. Grytten J. Trygdepolitiske problemstillinger i tannhelsetjenesten - en oversikt. Nor Tannlegeforen Tid 2010;120:308-15.

40. Grytten J. Payment systems and incentives in dentistry. Community Dent Oral Epidemiol 2017:45:1-11.

English Summary

\title{
Level of Education and Access to Subsidized Dental Care in Norway
}

\author{
JOSTEIN GRYTTEN, PROFESSOR, COMMUNITY DENTISTRY, FACULTY OF ODONTOLOGY, UNIVERSITY OF OSLO, \\ NORWAY
}

ICELANDIC DENTAL JOURNAL 2020; 38: 81-87

doi: 10.33112/tann.38.1.9

Equality in access to health services, including dental services, has been an important principle in the development of Scandinavian welfare policy. This principle has been an important justification for totally or partially subsidized dental care for adults. A common assumption is that the use of public subsidies reduces inequalities in access to services. In this paper, we summarize the results from a research project in which we tested this assumption.

This study was carried out with national and representative register data, using the introduction of 9 years of compulsory education in Norway to create variation in the length of education. The reform was introduced at the level of the municipalities during a period of 13 years, from 1960 to 1972. Before the reform compulsory education was 7 years. The reform can be seen as a natural experiment in which people were randomly selected into an experimental group (9 years compulsory schooling) and a control group (7 years compulsory schooling) according to factors beyond the control of the test subjects and the researchers. The results show inequalities in access to subsidized dental care, in favour of those with long education. The conclusion is that a welfare scheme based on subsidies is of most benefit to people with longer education.

Keywords: Dental services, children, social and financial aspects, oral health, prevention Correspondence: Jostein Grytten, Seksjon for samfunnsodontology, Universitetet i Oslo, Postboks 1052, Blindern, 0316 Oslo E-mail: josteing@odont.uio.no 